\title{
Inhibition of I $\kappa B-\alpha$ phosphorylation at serine and tyrosine acts independently on sensitization to DNA damaging agents in human glioma cells
}

\author{
J Miyakoshi ${ }^{1}$ and $\mathrm{K}$ Yagi $^{2}$ \\ ${ }^{1}$ Department of Radiation Genetics, Graduate School of Medicine and '2Department of Zoology, Graduate School of Science, Kyoto University, \\ Yoshida-Konoe-cho, Sakyo-ku, Kyoto 606-8501, Japan
}

\begin{abstract}
Summary Molecular mechanisms and/or intrinsic factors controlling cellular radiosensitivity are not fully understood in mammalian cells. The recent studies have suggested that nuclear factor $\kappa B(N F-\kappa B)$ is one of such factors. The activation and regulation of NF- $\kappa B$ are tightly

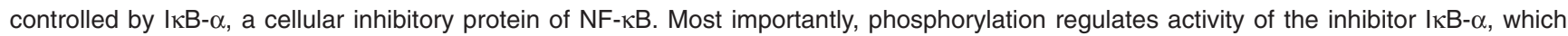
sequesters NF- $\mathrm{KB}$ in the cytosol. Two different pathways for the phosphorylation of IKB- $\alpha$ are demonstrated, such as serine (at residues 32 and 36 ) and tyrosine (at residue 42) phosphorylations. To assess a role of the transcription factor, NF-kB, on cellular sensitivity to DNA damaging agents, we constructed three different types of expression plasmids, i.e. S- $\mathrm{I} \mathrm{KB}$ (mutations at residues 32 and 36 ), Y-IKB (mutation at residue 42) and SY-IKB (mutations at residues 32, 36 and 42). The cell clones expressing S-IKB and Y-IKB proteins became sensitive to $\mathrm{X}$-rays as compared with the parental and vector-transfected cells. The cell clones expressing SY-IKB were further radiosensitive. By the treatment with herbimycin A, an inhibitor of phosphorylation, the X-ray sensitivity of cells expressing SY-IKB did not change, while that of the cells expressing $\mathrm{S}-\mathrm{I} \mathrm{KB}$ and $\mathrm{Y}-\mathrm{I} \mathrm{KB}$ and the parental cells was enhanced. Change in the sensitivity to adriamycin and UV in those clones was very similar to that in the $\mathrm{X}$-ray sensitivity. The inhibition of $\mathrm{I} \mathrm{KB}-\alpha$ phosphorylation at serine and tyrosine acts independently on the sensitization to X-rays, adriamycin and UV. These findings suggest that the transcriptional activation induced by NF- $\mathrm{KB}$ may play a role in the DNA damage repair. The present study proposes a possibility that the inactivation of NF-kB by inhibition of both serine and tyrosine phosphorylations may be useful for the treatment of cancer in radio- and chemotherapies. (C) 2000 Cancer Research Campaign
\end{abstract}

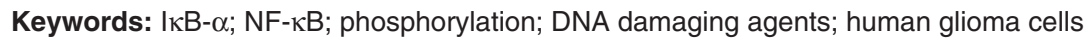

Ionizing radiation activates immediately early genes, such as c-jun, c-fos and nuclear factor $\kappa \mathrm{B}(\mathrm{NF}-\kappa \mathrm{B})$ (Hallahan et al, 1991; Wilson et al, 1993; Mohan and Meltz, 1994). The products of these genes are transcription factors involved in regulation of the gene expression associated with cell growth, healing of tissue injury and inflammation. Transfection with certain oncogenes has been found to cause cellular radiation resistance (Sklar, 1988; Kasid et al, 1989; Pirollo et al, 1993). These results suggest that related signalling pathways may be involved in acquisition of radiation resistance. It has been demonstrated that introduction of a truncated IKB- $\alpha$ corrected both hypersensitivity to ionizing radiation and the aberrant activation of NF- $\mathrm{KB}$ in ataxia telangectasia (AT) cells (Jung et al, 1995). Therefore, activation of transcription factor(s) may be involved in cellular radiosensitivity.

One of the proteins of the Rel/NF- $\kappa \mathrm{B}$ family, NF- $\kappa \mathrm{B}$, is a transcription factor which binds specifically to $\kappa \mathrm{B}$ motifs as homoor heterodimers and regulates the expression of many genes (reviewed in Baeuerle, 1991; Verma et al, 1995). The activation and regulation of NF- $\mathrm{KB}$ are tightly controlled by I $\kappa \mathrm{B}-\alpha$, a cellular inhibitory protein of NF- $\kappa$ B. Normally, I $\kappa B-\alpha$ binds to NF- $\kappa$ B, thereby preventing the translocation of $N F-\kappa B$ into nucleus

Received 14 January 1999

Revised 17 June 1999

Accepted 21 June 1999

Correspondence to: J Miyakoshi
(Baeuerle and Baltimore, 1988; Beg et al, 1992). Some of the stimuli including tumour necrosis factor- $\alpha$ (TNF- $\alpha$ ), ultra-violet (UV) and ionizing radiation cause the degradation and disappearance of IкB- $\alpha$ (Alkalay et al, 1995; Scherer et al, 1995), and then the NF- $\kappa \mathrm{B}$ translocates to the nucleus.

Phosphorylation is involved in the regulation of the activity of many transcription factors. The NF- $\mathrm{\kappa B}$ is a critical regulator of cytokine-inducible gene expression (Baeuerle and Henkel, 1994). Most importantly, phosphorylation regulates activity of the inhibitor I $\mathrm{KB}-\alpha$, which sequesters NF- $\kappa \mathrm{B}$ in the cytosol. For the activation of NF- $\kappa \mathrm{B}$, two different pathways for the phosphorylation of I $\mathrm{K} \mathrm{B}-\alpha$ are demonstrated. One is serine (at residues 32 and 36) phosphorylation, which induces subsequent ubiquitin-dependent degradation of I $\kappa$ B- $\alpha$ (Brockman et al, 1995; Brown et al, 1995; Traenckner et al, 1995). The other is tyrosine (at residue 42) phosphorylation, which has the potential to directly couple NF- $\kappa B$ to surface receptor associated tyrosine kinases, but not induce the degradation of IкB- $\alpha$ (Imbert et al, 1996).

We constructed three different types of expression plasmids, such as S-IKB containing Ser-to-Arg (AGC-CGC) mutations at residues 32 and 36, Y-IкB containing Tyr-to-Phe (TAC-TTC) mutation at residue 42 , and $\mathrm{SY}-\mathrm{I} \kappa \mathrm{B}$ containing all these mutations. To assess the role of NF- $\kappa B$ activation on cellular sensitivity to $\mathrm{X}$-rays, adriamycin and UV, we examined the sensitivity to these DNA damaging agents in human malignant glioma cells

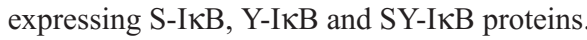




\section{MATERIALS AND METHODS}

\section{Cell lines and culture conditions}

The established human malignant glioma cell line, MO54, was used. The cells were kindly supplied from Dr RS Day, Cross Cancer Institute, Edmonton, AB, Canada. Cells were cultured in Dulbecco's modified Eagle medium plus 10\% fetal bovine serum (Hyclone Laboratories, Inc., Logan, UT, USA) at $37^{\circ} \mathrm{C}$ with $95 \%$ air and $5 \%$ carbon dioxide.

\section{Mutant constructions and transfections}

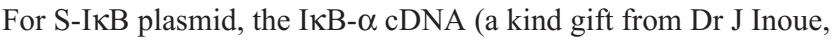
The Institute of Medical Science, University of Tokyo, Japan) inserted into the pBluescript II S/K plasmid was used as a template for further polymerase chain reaction (PCR) amplification. Mutagenic primers for ${ }^{32} \mathrm{Ser}$ to ${ }^{32} \mathrm{Arg}$ and ${ }^{36} \mathrm{Ser}$ to ${ }^{36} \mathrm{Arg}$, such as MAD-LPU; 5'-CGACCGCCACGACGCCGGCCTGGACGCCATGAAAGACG-3' and MAD-LPL; 5'-CGCTTTCATGGCGTCCAGGCCGGCGTCGTGGCGGTCG-3', were used in PCR reaction. The reaction mixture was as follows; $1 \mu \mathrm{l}$ of pB-MAD3 plasmid $\left(37 \mu \mathrm{g} \mathrm{ml}^{-1}\right), 1 \mu \mathrm{l}$ of each primer $(1 \mathrm{pmol}$ $\left.\mu 1^{-1}\right), 4 \mu \mathrm{l}$ of $25 \mathrm{~mm}$ magnesium chloride, $5 \mu \mathrm{l}$ of dNTP mix $(2 \mathrm{~mm}$ each), $0.5 \mu$ of KOD polymerase $\left(5\right.$ units $\left.\mu^{-1}\right), 5 \mu l$ of $10 \times$ KOD buffer and $34 \mu \mathrm{l}$ of distilled water. PCR condition was 15 cycles of $30 \mathrm{~s}$ at $98^{\circ} \mathrm{C}, 30 \mathrm{~s}$ at $55^{\circ} \mathrm{C}$ and $2 \mathrm{~min}$ at $74^{\circ} \mathrm{C}$ with a final extension at $72^{\circ} \mathrm{C}$ for $3 \mathrm{~min}$. The mixture was treated with $D p n \mathrm{I}$ for the degradation of the template plasmid. The plasmid sample was introduced into Escherichia coli JM109 strain by electroporation. After $1 \mathrm{~h}$ incubation with SOC medium, the cells were plated on LB dishes containing ampicillin. The S-IкB- $\alpha$ cDNA inserted in the pBluescript II $\mathrm{S} / \mathrm{K}$ plasmid were refined by using QIAprep Spin Miniprep kit (Qiagen, Germany) and checked by digestion with EcoRI. Then, sequencing of the S-I $\kappa \mathrm{B}-\alpha$ cDNA was done with a Prism Dye Primer Cycle Sequencing Kit (-21M13) (Applied Biosystems, Foster City, CA, USA). The pBluescript II $\mathrm{S} / \mathrm{K}$ plasmid containing S-IKB- $\alpha$ cDNA and the expression vector, pcDNA3 (Invitrogen, Leek, The Netherlands) were digested by HindIII and $X b a \mathrm{I}$. Then, the S-IкB- $\alpha$ cDNA was ligated into the HindIII and $X b a \mathrm{I}$ sites of pcDNA3 using DNA ligation kit ver. 2 (Takara, Ohtsu, Shiga, Japan). This plasmid was named as pcDNA3-S-IкB. For the Y-IкB plasmid, we used the mutagenic primers for ${ }^{42} \mathrm{Tyr}$ to ${ }^{42} \mathrm{Phe}$, such as MAD-YPU; 5'-GAAAGACGAGGAGTTCGAGCAGATGGTCAAGG-3' and MAD-YPL; 5'-CCTTGACCATCTGCTCGAACTCCTCGTCTTTC-3' in the

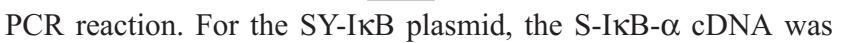
used as a template and the mutagenic primers for ${ }^{42} \mathrm{Tyr}$ to ${ }^{42} \mathrm{Phe}$ were used in PCR reaction. The expression plasmids of Y-IкB- $\alpha$ cDNA (pcDNA3-Y-IкB) and SY-IкB- $\alpha$ cDNA (pcDNA3$\mathrm{SY}$-IкB) were made by similar methods as above-mentioned. A plasmid pcDNA3, without I $\kappa \mathrm{B}-\alpha$ cDNA, was used as a negative control.

The methods of transfection were reported previously (Miyakoshi et al, 1997; Yamagishi et al, 1997a). Approximately $10^{6}$ cells of MO54 were transfected with $10 \mu \mathrm{g}$ of pcDNA3-S-IкB, pcDNA3-Y-I $\kappa$, pcDNA3-SY-I $\kappa$ B or pcDNA3 by the electroporation with the unit (model X-CELL 2000, pds Inc., Madison, WI, USA) operated at $800 \mathrm{~V}$. The cells were then cultured in normal medium for $36-48 \mathrm{~h}$, and then cultured in the medium containing G418 (400-800 $\left.\mu \mathrm{g} \mathrm{ml}^{-1}\right)$. The cultures were maintained for 2-3 weeks until colonies were formed. The transfection frequencies of these plasmids were $2-8 \times 10^{-4}$.

\section{Chemicals}

Human TNF- $\alpha$ (Pepro Tech EC Ltd., London, UK) was dissolved in distilled water and adriamycin (Wako Pure Chemical Industries, Ltd, Osaka, Japan) was dissolved in medium at a concentration of $20 \mu \mathrm{g} \mathrm{ml}^{-1}$ and $500 \mu \mathrm{g} \mathrm{m}^{-1}$ respectively. Herbimycin A (Sigma, St Louis, MO, USA) and genistein (Fujikko Ltd, Kobe, Japan) were dissolved in dimethylsulphoxide (DMSO) at a concentration of $2 \mathrm{mg} \mathrm{ml}^{-1}$ and $20 \mathrm{mg} \mathrm{ml}^{-1}$ respectively. These solutions were diluted in the medium at a final concentration and used for the experiments.

\section{Western immunoblots and immunoprecipitation}

Details of Western immunoblottings were described elsewhere (Miyakoshi et al, 1997). The antibodies used in this experiment were as follows; anti-IкB- $\alpha /$ MAD3 antibody (C-21, Santa Cruz Biotechnology, Inc., Santa Cruz, CA, USA), anti- $\beta$-actin antibody (Sigma) and anti-NFkB/p65 antibody (C-20, Santa Cruz Biotechnology). The immunoprecipitation was done by using Protein A Sepharose (Pharmacia Biotechnology). The nuclear extracts were prepared according to Schreiber et al (1989). Autoradiography with enhanced chemiluminescence was done according to the instructions by the manufacturer (Amersham International plc, Buckinghamshire, UK). The densitometric analysis was done by using NIH image 1.60.

\section{$X-$ and UV-irradiations and cell survival}

Methods of X- and UV-irradiations and the analysis of cell survival were described previously (Miyakoshi et al, 1996; Yamagishi et al, 1997b). X-irradiation was performed using a Hitachi MBR-1520 at $150 \mathrm{kVp}, 20 \mathrm{~mA}$ with $0.5 \mathrm{~mm} \mathrm{Al}$ and $0.1 \mathrm{~mm} \mathrm{Cu}$ filters with a dose-rate of $0.98-1.02 \mathrm{~Gy} \mathrm{~min}^{-1}$. For UV exposure, a bank of two $15 \mathrm{~W}$ Toshiba germicidal UV lamps (predominantly $254 \mathrm{~nm}$ ) was used with a dose rate of $1.2 \mathrm{~J} \mathrm{~m}^{-2} \mathrm{~s}^{-1}$. Control plating efficiencies for the parental MO54 cells and the transfected clones are ranged from 0.4 to 0.6 . Five replicate plates per experiment were used for each survival point and the experiments were repeated at least three times. Cell survival was statistically analysed by the two-way analysis of variance and by $t$-test for unpaired data.

\section{Detection of apoptosis}

Apoptosis Ladder Detection kit (Wako) was used. The cells were treated with TNF- $\alpha\left(20 \mathrm{ng} \mathrm{ml}^{-1}\right)$ for up to $12 \mathrm{~h}$. DNA was extracted and electrophoresed in agarose gel at $100 \mathrm{~V}$. The gel was stained with SYBR Green I (Molecular Probes, Eugene, OR, USA).

\section{Flow cytometry}

Analysis of cell cycle distribution was described previously (Miyakoshi et al, 1997). In brief, cells were suspended in phosphate-buffered saline (PBS) containing 0.1\% Triton X-100 after washing twice with PBS. RNAase $\left(1 \mathrm{mg} \mathrm{ml}^{-1}\right)$ (Sigma) was added to the cell suspension and the cells were incubated for $30 \mathrm{~min}$ at 


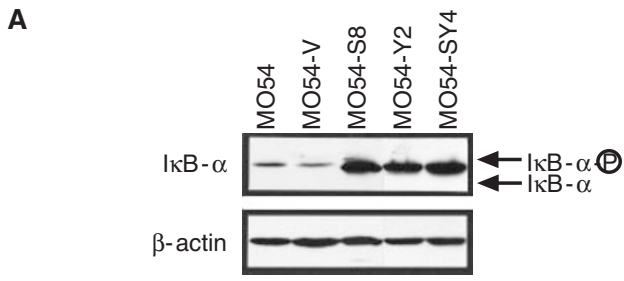

B

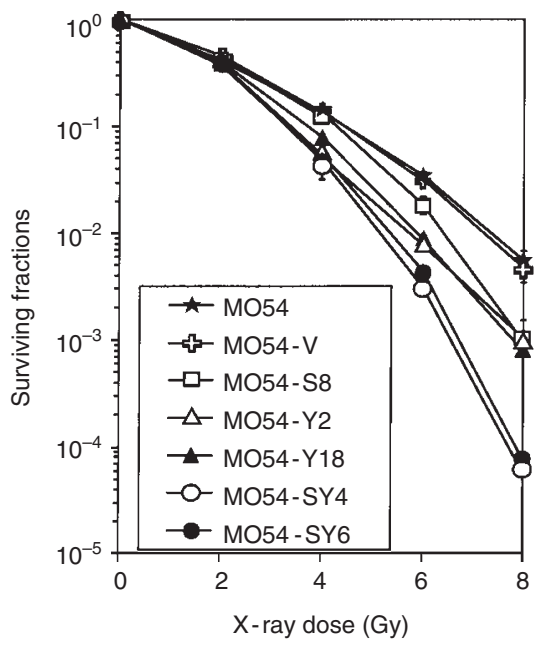

Figure 1 Expression of S-I $\mathrm{KB}, \mathrm{Y}-\mathrm{I} \mathrm{KB}$ and $\mathrm{SY}-\mathrm{I} \mathrm{\kappa B}$ proteins and X-ray sensitivity of the parental cells and the transfected clones. (A) The I $\mathrm{K} B-\alpha$ protein was detected using anti-IKB- $\alpha$ monoclonal antibody. After removing antibody, the same blot was re-probed with the anti- $\beta$-actin monoclonal antibody. (B) Exponentially growing cells were exposed to X-rays with various doses. Each point represents the mean of the triplicate experiments with standard deviation

$37^{\circ} \mathrm{C}$. Propidium iodide (Molecular Probes) was added at a final concentration of $50 \mu \mathrm{g} \mathrm{ml}^{-1}$ and the cell suspension was left at $4^{\circ} \mathrm{C}$ for $1 \mathrm{~h}$. The cells were filtered through $50 \mu \mathrm{m}$ nylon mesh before flow cytometry with a FACScan system (Becton Dickinson Co. Ltd, Franklin Lakes, NJ, USA).

\section{RESULTS}

\section{X-ray sensitivity of cells expressing S-IKB, Y-IKB and SY-IKB proteins}

The expressions of I $\mathrm{KB}-\alpha$ in the parental MO54 cells and their

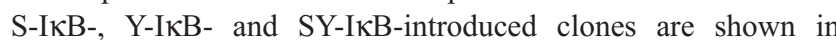
Figure 1A. The clones, MO54-S8, MO54-Y2 and MO54-SY4, were overexpressing $\mathrm{S}-\mathrm{I} \kappa \mathrm{B}, \mathrm{Y}-\mathrm{I} \kappa \mathrm{B}$ and $\mathrm{SY}-\mathrm{I} \kappa \mathrm{B}$ proteins respectively, in which those proteins were non-phosphorylated type. The radiation-dose survival curves of these clones, other expression clones MO54-Y18 and MO54-SY6, the parental MO54 and the negative control of MO54-V are shown in Figure 1B. MO54-S8, MO54-Y2 and MO54-Y18 cells became radiosensitive as compared with the parental MO54 and the vector-transfected MO54-V cells. The cell clones expressing SY-IкB, MO54-SY4 and MO54-SY6, were further radiosensitive. The radiosensitization was estimated from the ratio of mean surviving fraction for

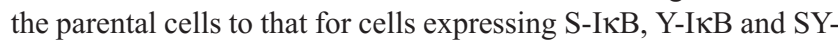
IкB (Table 1). The calculated additive radiosensitizing value was similar to the ratio of mean surviving fraction of cells expressing
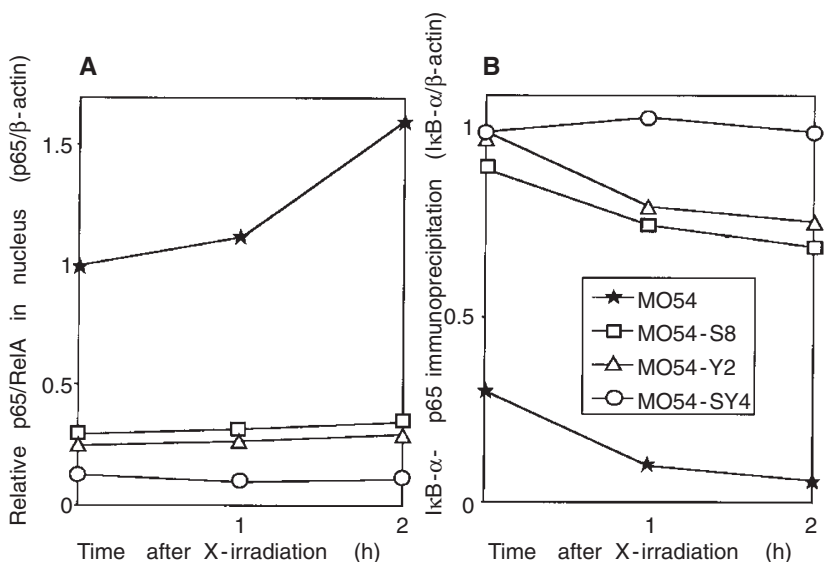

Figure 2 The relative p65/RelA protein in nuclear fraction and the relative amount of p65//кB- $\alpha$ complex in MO54-S8, MO54-Y2, MO54-SY4 and the parental MO54 cells after X-irradiation. (A) Nuclear extract was prepared from the cells at 1 or $2 \mathrm{~h}$ following $X$-irradiation with $8 \mathrm{~Gy}$. The p65/RelA protein was detected using anti-NFKB/p65 antibody. (B) After 1 or $2 \mathrm{~h}$ incubation following $\mathrm{X}$-irradiation with $8 \mathrm{~Gy}$, cell lysates were

immunoprecipitated with anti-NFKB/p65 antibody and then Western blot with anti-IкB- $\alpha$ monoclonal antibody was done. Each point represents the mean of the duplicate experiments. The densitometric analysis was done by using $\mathrm{NIH}$ image 1.60

SY-IкB. The extent of the radiosensitization in cells expressing SY-IкB was almost additive at higher doses of 4 Gy and over, which means addition of the radiosensitization in each clone

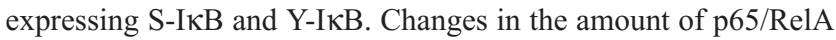
protein in nuclear fraction was examined in cells after $\mathrm{X}$-irradiation. The relative amount of $\mathrm{p} 65$ protein in nuclear fraction from MO54, MO54-S8, MO54-Y2 and MO54-SY4 cells after X-irradiation is shown in Figure 2A. The constitutive level of p65 in MO54-S8 and MO54-Y2 cells was lower than that in MO54 cells, but this level in MO54-SY4 cells was still lower. After X-irradiation, the amount of p65 in nucleus in MO54 cells was increasing, while that in these clones did not change significantly. The amount of I $\kappa \mathrm{B}-\alpha / \mathrm{NF}-\kappa \mathrm{B}$ complex was also examined after X-irradiation. The relative amount of $\mathrm{I} \kappa \mathrm{B}-\alpha$ immunoprecipitated with anti-NF$\kappa \mathrm{B} / \mathrm{p} 65$ after $\mathrm{X}$-irradiation is shown in Figure $2 \mathrm{~B}$. The constitutive level of I $\kappa \mathrm{B}-\alpha / \mathrm{NF}-\kappa \mathrm{B}$ complex observed in MO54-S8, MO54-Y2 and MO54-SY4 cells was higher than that in MO54 cells. After $\mathrm{X}$-irradiation, the amount of the complex in MO54-SY4 cells did not change, but the amount in MO54, MO54-S8 and MO54-Y2 cells was decreased. The I $\mathrm{KB}-\alpha / \mathrm{NF}-\kappa \mathrm{B}$ complex was dissociated and the amount was very low in MO54 cells after X-irradiation.

\section{Effect of herbimycin A on X-ray sensitivity}

We examined whether a phosphorylation inhibitor, herbimycin A, can modify cellular X-ray sensitivity. MO54-S8, MO54-Y2, MO54-Y18, MO54-SY4 and the parental cells were treated with herbimycin A $\left(1 \mu \mathrm{g} \mathrm{ml}^{-1}\right)$ for $2 \mathrm{~h}$, and then irradiated with X-rays. Herbimycin A was removed at $1 \mathrm{~h}$ after X-irradiation. Figure 3 shows the X-ray dose-survival curves of these cells. The X-raysurvival of MO54 cells was decreasing by herbimycin A, but did not reach to the radiosensitivity level of those cells expressing SY-IкB protein. The X-ray sensitivity of MO54-S8, MO54-Y2 and MO54-Y18 cells became almost similar level to that of 
Table 1 The radiosensitizing value estimated from the ratio of mean surviving fraction at 4,6 and 8 Gy

\begin{tabular}{|c|c|c|c|c|c|}
\hline \multirow[t]{2}{*}{ X-ray dose } & \multicolumn{5}{|c|}{ Ratio of mean surviving fraction [SF(parental cells)/SF(clones)] } \\
\hline & $\begin{array}{l}\text { Parental cells } \\
\text { (MO54) }\end{array}$ & $\begin{array}{l}\text { S-IкB clone } \\
\text { (M054-S8) }\end{array}$ & $\begin{array}{l}\text { Y-ІкB clones } \\
\text { (MO54-Y2) } \\
\text { (M054-Y18) }\end{array}$ & $\begin{array}{c}\text { SY-IкB clones } \\
\text { (MO54-SY4) } \\
\text { (M054-SY6) }\end{array}$ & $\begin{array}{c}\text { Calculated } \\
\text { additive } \\
\text { radiosensitizing } \\
\text { value }^{*}\end{array}$ \\
\hline 4 Gy & $(1.00)$ & 1.36 & 2.52 & 3.75 & 3.43 \\
\hline 6 Gy & $(1.00)$ & 2.15 & 4.70 & 10.66 & 10.11 \\
\hline 8 Gy & $(1.00)$ & 7.11 & 8.50 & 70.59 & 60.44 \\
\hline
\end{tabular}

The radiosensitizing value was estimated from the ratio of mean surviving fraction for the parental cells (MO54) to that for clones

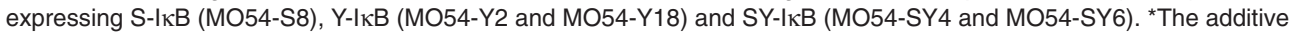
radiosensitizing value for $\mathrm{SY}-\mathrm{I} \kappa \mathrm{K}$ was calculated as a multiplication of the surviving fraction ratio for $\mathrm{S}-\mathrm{I} \kappa \mathrm{B}$ and that for $\mathrm{Y}-\mathrm{I} \kappa \mathrm{B}$.

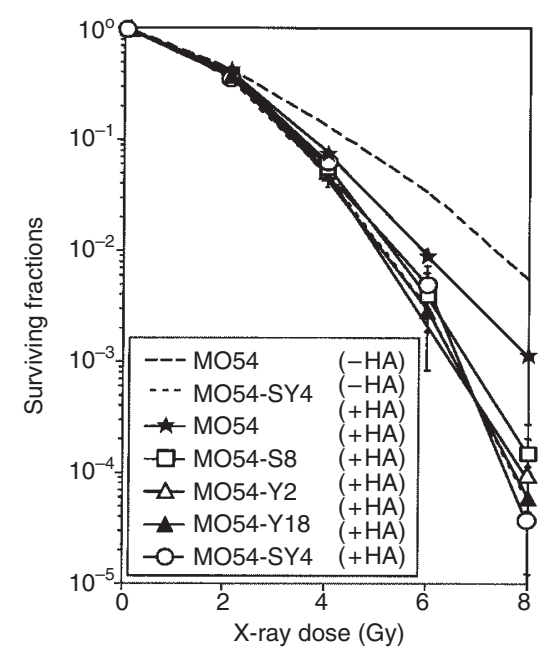

Figure 3 Effect of herbimycin A on the X-ray sensitivity of the cells

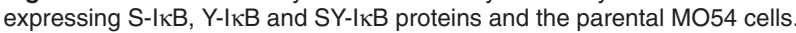
Exponentially growing cells were treated with herbimycin $A\left(1 \mu \mathrm{g} \mathrm{ml}^{-1}\right)$ for $2 \mathrm{~h}$ and then exposed to X-rays with various doses. Herbimycin A was removed at $1 \mathrm{~h}$ after $\mathrm{X}$-irradiation. Each point represents the mean of the triplicate experiments with standard deviation

MO54-SY4 cells. However, the radiosensitivity of MO54-SY4 cells did not change by the treatment with herbimycin A. Treatment with the other inhibitor, genistein $\left(100 \mu \mathrm{g} \mathrm{ml}^{-1}\right)$, showed a similar trend to herbimycin A (data not shown).

\section{Effect of TNF- $\alpha$ on DNA degradation, cell cycle distribution and $X$-ray sensitivity}

We examined the effect of TNF- $\alpha$, one of the phosphorylation stimuli, on DNA degradation, cell cycle distribution and X-ray sensitivity. MO54-S8, MO54-Y2, MO54-SY4 and the parental cells were treated with TNF- $\alpha\left(20 \mathrm{ng} \mathrm{ml}^{-1}\right)$ for up to $12 \mathrm{~h}$. Figure $4 \mathrm{~A}$ shows the photographs of DNA gels. TNF- $\alpha$-induced DNA degradation was observed in MO54-S8, MO54-Y2 and MO54SY4 cells. The parental MO54 cells did not occur such DNA degradation for up to a $12 \mathrm{~h}$ treatment with TNF- $\alpha$. Patterns of cell cycle distribution after $\mathrm{X}$-irradiation or TNF- $\alpha$ treatment are shown in Figure 4B. Typical G1 arrest and a decrease in S phase ratio were observed in MO54 but not in MO54-SY4 cells after $\mathrm{X}$-irradiation. DNA degradations by the treatment with TNF- $\alpha$ for
A
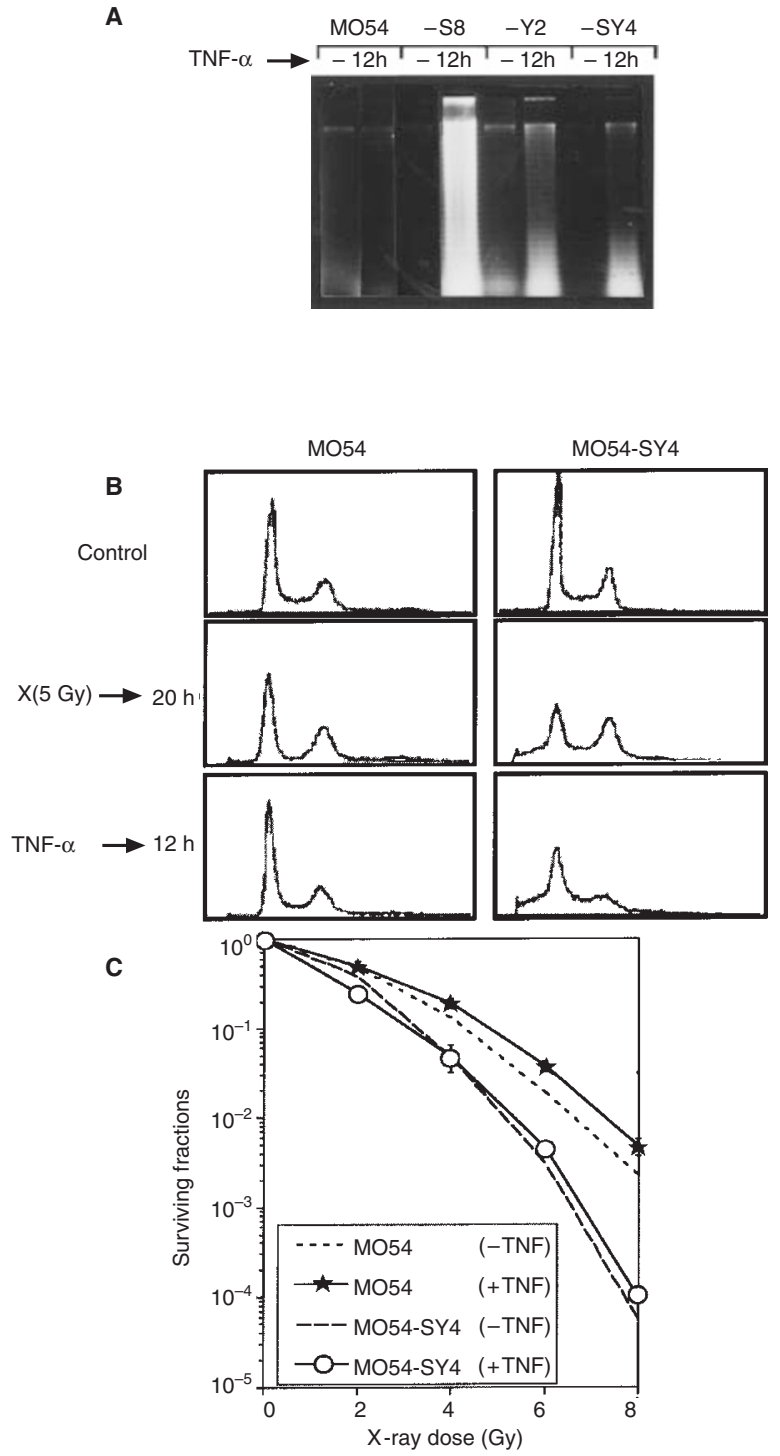

Figure 4 Ethidium bromide-stained gels, cell cycle distribution and the $X$-ray sensitivity of cells treated with TNF- $\alpha$. (A) MO54-S8, MO54-Y2, MO54SY4 and the parental MO54 cells were treated with TNF- $\alpha\left(20 \mathrm{ng} \mathrm{ml}^{-1}\right)$ for up to $12 \mathrm{~h}$. DNA from those cells was extracted and electrophoresed.

(B) Exponentially growing MO54 and MO54-SY4 cells were exposed to X-rays with 5 Gy followed by a $20 \mathrm{~h}$ incubation or treated with TNF- $\alpha\left(20 \mathrm{ng} \mathrm{ml}^{-1}\right)$ for $12 \mathrm{~h}$, and then cell cycle distribution was analysed by quantitative flow cytometry. Each experiment was repeated twice. (C) Exponentially growing cells were treated with TNF- $\alpha\left(20 \mathrm{ng} \mathrm{ml}^{-1}\right)$ for $4 \mathrm{~h}$ and then exposed to X-rays with various doses. TNF- $\alpha$ was removed at $4 \mathrm{~h}$ after $X$-irradiation. Each point represents the mean of the triplicate experiments with standard deviation 


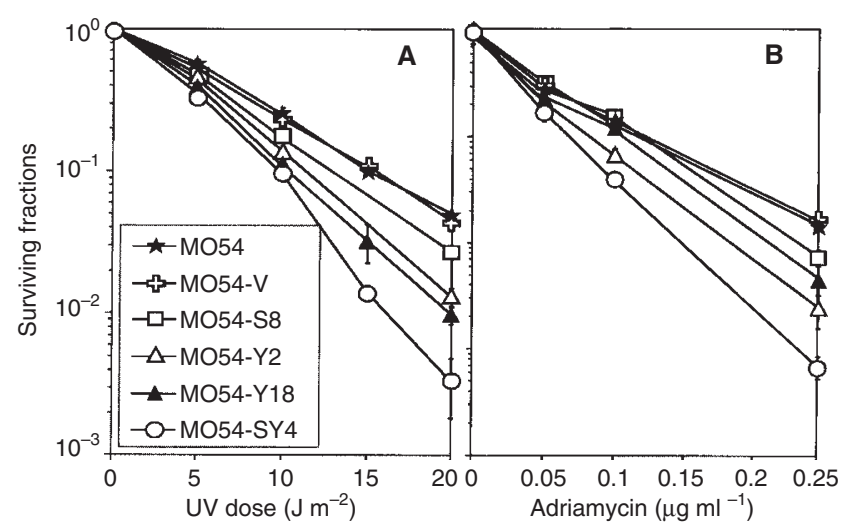

Figure 5 Adriamycin and UV sensitivities of cells expressing $S-I \kappa B, Y-I \kappa B$ and SY-I $\mathrm{KB}$ proteins. Exponentially growing cells were exposed to $(\mathbf{A}) \mathrm{UV}$ with various doses or treated with (B) adriamycin for $2 \mathrm{~h}$. Each point represents the mean of the triplicate experiments with standard deviation

$12 \mathrm{~h}$ were detected in MO54-SY4 but not in the parental MO54 cels.

MO54-SY 4 and MO54 cells were treated with TNF- $\alpha$ for $4 \mathrm{~h}$ and then irradiated with X-rays. TNF- $\alpha$ was removed at $4 \mathrm{~h}$ after $\mathrm{X}$-irradiation. Figure $4 \mathrm{C}$ shows the $\mathrm{X}$-ray dose-survival curves of those cells. The toxicity of TNF- $\alpha$ alone, in which the surviving fraction was 0.61 for MO54-SY4, was normalized in the survival curves. No decrease in survival was observed in MO54 cells after treatment with TNF- $\alpha$. The radiosensitivity of MO54-SY4 cells did not change by the treatment with TNF- $\alpha$. The X-ray-survival of MO54 cells at doses of 6 and 8 Gy was increasing slightly by the treatment with TNF- $\alpha(P<0.05)$.

\section{Adriamycin and UV sensitivities}

We examined the cellular sensitivity to other DNA damaging agents, adriamycin and UV. Cell survival after adriamycin treatment or UV-irradiation in MO54-S8, MO54-Y2, MO54-Y18, MO54-SY4, MO54-V, and the parental cells are shown in Figure 5A and 5B. MO54-S8, MO54-Y2 and MO54-Y18 cells were sensitive to adriamycin and UV. MO54-SY4 cells were further sensitive to the both, the extent of the sensitization to adriamycin and UV in cells expressing SY-IKB also being additive. Change in the sensitivity to adriamycin and UV in those clones showed a very similar trend to that in the X-ray sensitivity.

\section{DISCUSSION}

For the activation of NF- $\kappa \mathrm{B}$, two different pathways for the phosphorylation of I $\mathrm{B}-\alpha$ are demonstrated, one for serine (at residues 32 and 36) phosphorylation and the other for tyrosine (at residue 42) phosphorylation. Wang et al (1996) reported that inhibition of

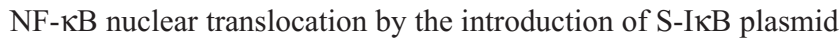
into human fibrosarcoma cell line HT 1080 enhanced cell killing by ionizing radiation. Our finding using MO54-S8 cells in this study is consistent with their data (Figure 1B). In addition, the clones expressing $\mathrm{Y}-\mathrm{I} \kappa \mathrm{B}$ protein became radiosensitive and the clones expressing SY-IKB protein were further radiosensitive (Figure 1B). The extent of radiosensitization in cells expressing
SY-I $\kappa B$ is almost additive (Table 1). Changes in the nuclear fraction of p65/Rel protein and the amount of NF- $\mathrm{BB} / \mathrm{I} \kappa \mathrm{B}-\alpha$ complex after $\mathrm{X}$-irradiation also depended on the status of IкB- $\alpha$ phosphorylation (Figure 2). Therefore, the inhibition of phosphorylation at serine and tyrosine of IкB- $\alpha$ acts independently on the radiosensitization of the cells.

Phosphorylation pathways are important for NF- $\kappa$ B activation. Treatment with a phosphorylation inhibitor, herbimycin A or genistein, inhibits radiation-induced NF- $\kappa$ B activation (Iwasaki et al, 1992; Uckun et al, 1993). The X-ray sensitivity of MO54-SY4 cells did not change by the treatment with herbimycin A, while that of the parental MO54 cells was enhanced by herbimycin A (Figure 3). Genistein had a similar effect of herbimycin A on the $\mathrm{X}$-ray sensitivity of those cells (data not shown). Inhibition of phosphorylations by herbimycin A sensitized cells to X-rays, supports that the radiosensitization of cells expressing S-I $\mathrm{KB}, \mathrm{Y}-$

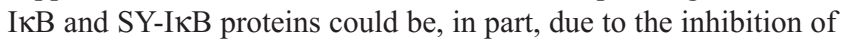
IкB- $\alpha$ phosphorylation.

The phosphorylation of IKB- $\alpha$ is induced by a variety of activators, such as TNF- $\alpha, 12-O$-tetradecanoylphorbol-13-acetate (TPA) and interleukin (IL)-1, resulting in the induction of NF- $\mathrm{KB}$ activation (Beg et al, 1993; Brown et al, 1993; Cordle et al, 1993; Mellits et al, 1993). The expression of S-IкB protein potentiately enhanced the ability of TNF- $\alpha$ to initiate apoptosis in a variety of cells that are normally resistant to this cytokine, suggests that the activation of NF- $\mathrm{KB}$ by TNF- $\alpha$ is protective (Wang et al, 1996). Treatment with TNF- $\alpha$ induced DNA degradation in MO54-S8, MO54-Y2 and MO54-SY4 cells, but not in the parental MO54 cells (Figure 4A). The results of cell cycle distribution of MO54SY4 and MO54 cells supported these observations (Figure 4B). By the treatment with TNF- $\alpha$, X-ray survivals of MO54-SY4 cells did not change significantly, but those of MO54 cells increased slightly (Figure 4C). Thus, the absence of NF- $\mathrm{KB} / \mathrm{p} 65$ sensitized cells to TNF- $\alpha$, but an increase in cell killing induced by $\mathrm{X}$-irradiation in MO54-SY4 might be independent of the toxic action of TNF- $\alpha$, such as an induction of DNA degradation. In addition, TNF- $\alpha$-induced activation of NF- $\kappa B$ in MO54 cells may provide protection against cell killing by $\mathrm{X}$-rays.

For the response of cells to other DNA damaging agents, such as adriamycin and UV, MO54-S8, MO54-Y2, MO54-Y18 and MO54-SY4 cells became sensitive as compared with the parental MO54 cells (Figure 5). In addition, changes in the sensitivity to adriamycin and UV in those clones showed a very similar trend to that in the X-ray sensitivity and the extent of these sensitizations in cells expressing SY-IкB was also additive (Figure 5). Therefore, the sensitization of those cells to adriamycin and UV was also independently induced by the inhibition of serine and tyrosine phosphorylations in I $\mathrm{B}-\alpha$.

In the treatment of cancer, sensitivity or resistance of tumour cells to ionizing radiation and anti-tumour chemical agents has been substantial clinical consequences. However, molecular mechanisms and/or intrinsic factors controlling these cellular sensitivities are not fully understood in mammalian cells. In the present study, an inactivation of NF- $\mathrm{KB}$ by inhibition of both phosphorylations at serine and tyrosine of I $\mathrm{KB}-\alpha$ enhances the sensitivity to $\mathrm{X}$-rays and adriamycin in glioma cell line. The present findings suggest that the transcriptional activation induced by NF- $\mathrm{KB}$ may play a role in the repair of DNA damages. The present study also proposes a possibility that the inactivation of NF- $\kappa B$ by inhibition of both serine and tyrosine phosphorylations may be useful for the treatment of cancer in radio- and chemotherapies. 


\section{ACKNOWLEDGEMENTS}

We are grateful to A Yamada, M Yoshida and H Yaguchi for excellent technical assistant in tissue culture. The cooperations of Drs J Inoue and RS Day for supplies of IKB- $\alpha$ cDNA and human malignant glioma cell lines, respectively, are gratefully acknowledged. This work was supported in part by a Grant-in-Aid for Scientific Research on Priority Areas (09255227 and 10153232) from the Ministry of Education, Science, Sports and Culture, Japan.

\section{REFERENCES}

Alkalay I, Yaron A, Hatzubai A, Orian A, Ciechanover A and Ben-Neriah Y (1995)

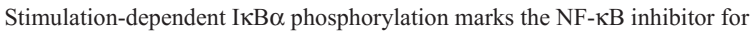
degradation via the ubiquitin-proteasome pathway. Proc Natl Acad Sci USA 92: 10599-10603

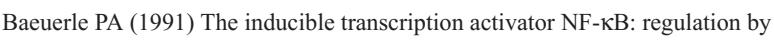
distinct protein subunits. Biochim Biophys Acta 1072: 63-80

Baeuerle PA and Baltimore D (1988) IкB- $\alpha$ : a specific inhibitor of the NF- $\kappa B$ transcription factor. Science 242: 540-546

Baeuerle PA and Henkel T (1994) Function and activation of NF- $\kappa B$ in immune system. Annu Rev Immunol 12: 141-179

Beg AA, Rubin SM, Scheinman RI, Haskill S, Rosen CA and Baldwin AS (1992) $\mathrm{I} \kappa \mathrm{B}$ interacts with the nuclear locatization sequencers of the subunits of NFКB: a mechanism for cytoplasmic retention. Genes Dev 6: 1899-1913

Beg AA, Finc TS, Nantermet PV and Baldwin AS Jr (1993) Tumor necrosis factor and interleukin-1 lead to phosphorylation and loss of IאB- $\alpha$ : a mechanism for NF- $\kappa B$ activation. Mol Cell Biol 13: 13301-13310

Brockman JA, Scherer DC, McKinsey TA, Hall SM, Qi X, Young Lee W and Ballard DW (1995) Coupling of a signal response domain in $\mathrm{I} \kappa \mathrm{B} \alpha$ to multiple pathways for NF- $\mathrm{KB}$ activation. Mol Cell Biol 15: 2809-2818

Brown K, Park S, Kanno T, Franzoso G and Siebenlist U (1993) Mutual regulation of the transcriptional activator NF- $\kappa \mathrm{B}$ and its inhibitor, I kappa B- $\alpha$. Proc Natl Acad Sci USA 90: 2532-2536

Brown K, Gerstberger S, Carlson L, Franzoso G and Siebenlist U (1995) Control of I $\mathrm{B}-\alpha$ proteolysis by site-specific, signal-induced phosphorylation. Science 267: $1485-1488$

Cordle SR, Donald R, Read MA and Hawiger J (1993) Lipopolysaccharide induces phosphorylation of MAD3 and activation of c-Rel and related NF- $\kappa B$ proteins in human monocytic THP-1 cells. J Biol Chem 268: 11803-11810

Hallahan DE, Sukhatme VP, Sherman ML, Virudaghalam S, Kufe D and Weichselbaum RR (1991) Protein kinase C mediates X-ray inducibility of nuclear signal transducers EGR1 and JUN. Proc Natl Acad Sci USA 88: 2156-2160

Imbert V, Rupec RA, Livolsi A, Pah HL, Traenckner EB-M, Mueller-Dieckman C, Farahifer D, Rossi B, Auberger P, Baeuerle PA and Peyron J-F (1996) Tyrosine phosphorylation of I $\kappa \mathrm{B}-\alpha$ activates NF- $\kappa \mathrm{B}$ without proteolytic degradation of IкB- $\alpha$. Cell 86: 787-798

Iwasaki T, Uehara Y, Gravea L, Rachie N and Bomsztyk K (1992) Herbimycin A blocks IL-1-induced NF- $\mathrm{KB}$ DNA-binding activity in lymphoid cell lines. FEBS Lett 298: 240-244
Jung M, Zhang Y, Lee S and Dritschilo A (1995) Correction of radiation sensitivity in Ataxia Telangiectasia cells by a truncated IкB- $\alpha$. Science 268: 1619-1621

Kasid U, Pfeifer A, Brenman T, Beckett M, Weichselbaum RR, Dritschilo A and Mark GE (1989) Effect of antisense c-raf-1 on tumorigenicity and radiation sensitivity of a human squamous carcinoma. Science 243: 1354-1356

Mellits KH, Hay RT and Goodbourn S (1993) Proteolytic degradation of MAD3

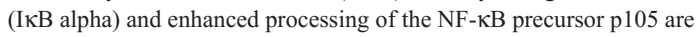
obligatory steps in the activation of NF- $\mathrm{\kappa B}$. Nucelic Acids Res 21: 5059-5066

Miyakoshi J, Yamagishi N, Ohtsu S and Takebe H (1995) Changes in radiation sensitivity of human osteosarcoma cells after p53 introduction. Jap J Cancer Res 86: 711-713

Miyakoshi J, Yamagishi N, Ohtsu S, Mohri K and Takebe H (1996) Exposure to magnetic field $(5 \mathrm{mT}$ at $60 \mathrm{~Hz})$ does not affect cell growth and c-myc gene expression. Mutat Res 349: 109-114

Miyakoshi J, Kitagawa K, Yamagishi N, Ohtsu S, Day RS III and Takebe H (1997) Increased radiosensitivity of p16 gene-deleted human glioma cells after transfection with wild-type p16 gene. Jap J Cancer Res 88: 34-38

Morhan N and Meltz ML (1994) Induction of nuclear factor $\kappa B$ after low-dose ionizing radiation involves a reactive oxygen intermediate signaling pathway. Radiat Res 140: 97-104

Pirollo KF, Tong YA, Villegas Z, Chen Y and Chang EH (1993) Oncogenetransformed NIH 3 T3 cells display radiation resistance levels indicative of a signal transduction pathway leading to the radiation-resistant phenotype. Radiat Res 135: 234-243

Scherer DC, Brockman JA, Chen Z, Maniatis T and Ballard DW (1995) Signalinduced degradation of $\mathrm{I} \kappa \mathrm{B} \alpha$ requires site-specific ubiquitination. Proc Natl Acad Sci USA 92: 11259-11263

Schreiber E, Matthias P, Mulle MM and Schaffner W (1989) Rapid detection of octamer binding proteins with 'mini-extracts', prepared from a small number of cells. Nucleic Acids Res 17: 6419

Sklar MD (1988) The ras oncogenes increase the intrinsic resistance of HIH 3T3 cells to ionizing radiation. Science 239: 645-647

Traenckner EB-M, Pahl HL, Henke T, Schmidt KN, Wilk S and Baererle PA (1995)

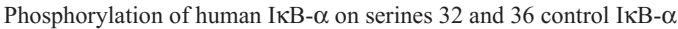
proteolysis and NF- $\mathrm{KB}$ activation in response to diverse stimuli. EMBO J14: 2876-2883

Uckun FM, Schieven GL, Tuel-Ahlgren LM, Dibirdik I, Myers DE, Ledbetter JA and Song CW (1993) Tyrosine phosphorylation is a mandatory proximal step in radiation-induced activation of the protein kinase $\mathrm{C}$ signaling pathway in human B-lymphocyte precursors. Proc Natl Acad Sci USA 90: 252-256

Yamagishi N, Miyakoshi J and Takebe H (1997a) Decrease in the frequency of $\mathrm{x}$-ray-induced mutation by wild-type $\mathrm{p} 53$ protein in human osteosarcoma cells. Carcinogenesis 18: 695-700

Yamagishi N, Miyakoshi J, Yagi T and Takebe H (1997b) Suppression of UVinduced mutation by wild-type $\mathrm{p} 53$ protein in human osteosarcoma cells. Mutagenesis 12: 191-194

Verma IM, Stevenson JK, Schwarz EM, Van Antwerp D and Miyamoto S (1995)

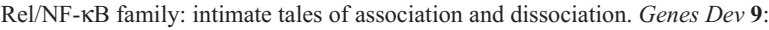
$2723-2735$

Wang C-Y, Mayo MW and Baldwin AS Jr (1996) TNF- and cancer therapy-induced apoptosis: potentiation by inhibition of NF-KB. Science 274: 784-787

Wilson RE, Taylor SL, Atherton GT, Johnston D, Waters CM and Norton JD (1993) Early response gene signalling cascades activated by ionizing radiation in primary human B cells. Oncogene 8: 3229-3237 